\title{
The United States and Latin America Regional Cooperation: Organization of American States (OAS)
}

\author{
Demeiati Nur Kusumaningrum ${ }^{1}$ \\ demeiati.nk@umm.ac.id
}

\begin{abstract}
Abstrak
Penelitian ini berpendapat bahwa perjanjian kerja sama OAS menjadi instrumen Amerika Serikat untuk mencapai kepentingan keamanan dan ekonomi. Semangat untuk menyebarkan kebebasan dan hak asasi manusia dianggap sebagai karakter AS sebagai negara demokrasi liberal. Pemerintahan Obama mengambil kesempatan lebih besar untuk memperkuat kerja sama dengan negara-negara Amerika Latin melalui OAS sebagai sarana untuk merebut kekuasaan dan pengaruh yang berkaitan dengan masalah perjanjian perdagangan bebas Amerika Latin dan kontrol terhadap penyelundupan narkoba. Penelitian ini menggunakan metode penelitian kualitatif dengan analisis deskriptif. Data dan informasi diperoleh dari kajian pustaka. Peneliti menerapkan analisis konten dokumen melalui publikasi pemerintah, publikasi ilmiah, dan laporan. Perubahan kebijakan luar negeri AS di bawah pemerintahan Obama percaya pada reformasi pasar dan pragmatisme Amerika berdasarkan demokrasi dan liberalisasi perdagangan. Kemajuan ekonomi Mercosur memicu kepercayaan terhadap kemajuan pembangunan di antara negara-negara Amerika Latin dan membuat mereka menjauhi pengaruh politik AS. Sementara itu, keamanan nasional AS terancam oleh meningkatnya perdagangan narkoba dari Meksiko dan kawasan selatan sejak tahun 1980-an. Kerangka kerja kerja sama OAS dalam memerangi perdagangan narkoba yang dikembangkan oleh AS sebagai aktor dominan melegitimasi pengaruh AS dalam forum regional. Dengan memperkuat kerja sama AS dan Amerika Latin pada pengendalian obat-obatan, pemerintah AS mampu memanfaatkan berkembangnya ekonomi Mercosur dan merealisasikan kebijakan AS tentang pengendalian narkoba di seluruh kawasan Amerika.
\end{abstract}

Kata kunci: Amerika Latin, Ekonomi Politik, Keamanan, Kepentingan, Regionalisme

\begin{abstract}
This research argue on the OAS cooperation agreement becomes United States instrument to achieve the political economy and political security. The spirit to spread of freedom and human right perceived as the character of US as a liberal democratic country. The Obama administration take a greater chance to strengthened the cooperation with Latin American countries by the OAS as a means to seize power and influence dealt with the matter of Latin America free trade agreement and drugs control. This research used qualitative research method by descriptive analysis. The data and information obtained from library research. The researcher apply document content analysis through the government publications, scholars publications, IGO reports, and other research publication. The foreign policy changes of US foreign policy under Obama administration believe in market reform and American pragmatism based on democracy and trade liberalization. The economic advancement of Mercosur triger the confidence building among Latin America countries and let them survive without US political influence. Whereas, US national security threaten by the increasing of drug trafficking from Mexico and southern area since 1980s. The OAS framework of cooperation on combating drugs trafficking developed by US as the dominant

1 Korespondensi: Demeiati Nur Kusumaningrum. Program Studi Ilmu Hubungan Internasional. Universitas Muhammadiyah Malang. Gedung Kuliah Bersama (GKB) I. Jl. Raya Tlogomas No.246 Malang 65144. (0341)464318 - 26 Ext.248
\end{abstract}


actor to legitimate the US influence in American regional forum. By strengthening the US and Latin America cooperation on drugs control the US administration is able to contribute to the economic benefits of Mercosur and achieve US policy on drug control throughout the American region.

Keywords: Interest, Latin America, Political Economy, Regionalism, Security

\section{Introduction}

United States and Latin American relations based on framework of cooperation in the Organization of American States (OAS) becomes the core of analysis of this paper. Latin America states in this research refers to Argentina, Brazil, Paraguay, Uruguay, and Venezuela. The five prominent countries acknowledged as the founder of Mercosur. Its purpose is to promote free trade and the economic integration of Latin American states. Mercosur - the latin America trade bloc- was formed on 26 March 1991 and becomes the world largest regional economic organization after European Union (EU), North American Free Trade Area (NAFTA), and the Association of South East Asian Nations (ASEAN). Mercosur's full member states are also supported by six associate nations from Chile, Columbia, Equador, Peru, Guyana, and Suriname. It achieves GDP approximately $\$ 4.58$ trillion USD (82 percent total of South America) and is home to some 275 million people (almost 70 percent of South America population). By considering the similarity of ideological left-wing government and the economic strength, Mercosur has taken on an increasingly sicnificant social and political role in the region (Chatterjee, 2016).

Latin America becomes important to the United States. Mexico in 2007 is the second largest (after Canada) US trading partner in the world. Hispanics have become the US largest minority population. The several transnational issue including drugs, trade, immigration, tourism, pollution, investment, the environment, democracy, and human rights signed the political discourse between US and Latin American countries. The cooperation on development between Latin America and Asian and European countries seems to be the chellenges of US influence in the region (Wiarda \& Kline, 2007).

Washington D.C. becomes the historical place marked the establishment of the idea to create the regional cooperation named the Organization of American States (OAS). The First International Conference of American States from October 1889 to 1890 resulted the approval of International Union of American Republics 
and set of provisions that came to be known as the inter-American system. The OAS came into being in 1948 with the signing in Bogota, Colombia. Its objective focuses on four pillars; democracy, human rights, security, and development (OAS, 2017d). The Charter of the OAS entered into force in December 1951. The organization is growing more effective through the sets of provisions amended in Protocol of Buenos Aires (1967), Protocol of Cartagena de Indias (1985), Protocol of Managua (1993), and Protocol of Washington (1997).

The goals of the organization is stipulated in Article 1 of the Charter in which all of the member states agree to achieve -"an order of peace and justice, to promote their solidarity, to strengthen their collaboration, and to defend their soverignty, their territorial integrity, and their independence". The OAS consists of 35 independent states and granted 69 permanent observer include European Union (OAS, 2017d).

Regional co-operation is an essential element of stabilisation and association - the process guiding the countries toward its membership - aimed to helps the region to address shared challenges (European Commission 2016). Regional cooperation and integration (RCI) is a process by which national economies become more interconnected regionally. RCI plays a critical role in accelerating economic growth, reducing poverty and economic disparity, raising productivity and employment, and strengthening institutions (Asian Development Bank 2017). Based on the background, this paper would like to question, 1) How is the US and Latin America relations based on the OAS framework of cooperation?; 2) What is the interests of the United States on regional cooperation?”.

\section{Literature Review}

United States settled in America region. It is a region that involves several countries belong to North America, Central America, and South America. Those countries have the character of government based on socialist and liberal ideology. Richard C. Williamson, in "Latin American Societies in Transition", suggests that in broad ethnic terms the countries of Latin America could be classified into four major groups; 1) Countries in which a mestizo population dominates, 2) Countries overwhelmingly European in character, 3) Countries with conspicous 
Indian grouping, generally inhabiting the highland, and 4) Countries dominated by African admixtures. The first group countries includes the South American countries of Venezuela and Columbia, as well as Nicaragua, El Salvador, Honduras, and Panama in Central America and Mexico. The second group consists of predominantly European countries such as Argentina, Chile, Uruguay, and Costa Rica. The third group which acknowledged by the large of Indian groups are Guatemala, Ecuador, Peru, Bolivia, and Paraguay. The forth group of countries which dominated by African admixtures are Brazil, and the Caribbean countries of Cuba, the Dominican Republic, and Haiti (Wiarda \& Kline, 2007).

Based on the recommendation of Congressional Research Service in 2012, the Obama administration should concern on the relation of US and Latin America countries by respecting the geographical, security, and economic background.

Geographic proximity has ensured strong linkages between the United States and the Latin American and Caribbean region, with diverse U.S. interests, including economic, political and security concerns. Current U.S. policy toward the region is focused on four priorities: promoting economic and social opportunity; ensuring citizen security; strengthening effective democratic institutions; and securing a clean energy future. There has been substantial continuity in U.S. policy toward the region under the Obama Administration, which has pursued some of the same basic policy approaches as the Bush Administration. Nevertheless, the Obama Administration has made several significant policy changes, including an overall emphasis on partnership and shared responsibility. U.S. policy toward the region must also contend with a Latin America that is becoming increasingly independent from the United States. Strong economic growth has increased Latin America's confidence in its ability to solve its own problems. The region has also diversified its economic and diplomatic ties with countries outside the region. Over the past few years, several Latin American regional organization have been established that do not include the United State (Sullivan et al., 2012).

Foreign policy is explained as the decision governing authorities make in the name of the state to realize international goals (Kegley Jr. \& Wittkopf, 1999). Moreover, Mark R. Amstutz (1995) defined it as an explicit and implicit actions of governmental officials designed to promote national interests beyond a country's territorial boundaries (Jemadu, 2008). The US foreign policy to Latin America due to the optimalization of the framework of cooperation in the OAS, is able to analyze by using the propositions of neoliberal theory. 
Neoliberal theory posits that formal international institutions can make international cooperation easier to attain than in their absence. International institutions reflect the general, embedded framework of international principles, rules, norms, and decision making procedures around which states seeking to maximize their interests will converge (Krasner 1983; Keohane 1989). Neoliberal theory looks the state behavior in formal international institutions as evidence that, in an independent world, states will seeks efficiency in managing collective problems presented by international anarchy. International institutions also helps states to both define acceptable international behavior and to provide for a means of punishing defectors from agreed coomunity standards. Traditionally, neoliberal institution theory focused on economic and environmental cooperation, whereas security studies were dominated by the classical realist and neorealist schools of IRs (Jackson \& Sorensen, 1999).

\section{Methods}

The data and information obtained from the library research. Primary data analysis focus on the online publication content of US government website, the OAS website, the Mercosur website, and government official websites of Latin America countries in America region. The technique of data analysis lies on the document content analysis. The literature review acknowledged from the online and printed of research publication from the scholars and official publication on the topics of US foreign policy and the relation between US, Latin America, Mercosur, and the OAS.

\section{Result and Discussion}

This research focusses on the US foreign policy under Obama administration to the Latin America countries through the OAS framework of cooperation on development. It will explain how the US security and economic interests becomes the political consideration of its administration regarding the issue of drug trafficking.

\section{The OAS response to Drugs Problem}


The OAS is very dedicated to combating this problem and has many projects focused on supply and demand reduction and developing stronger anti-drug institutions within individual states (OAS, 2017b). It established CICAD (The InterAmerican Drug Abuse Control Commission). CICAD is the Western Hemisphere's policy forum for dealing with the drug problem. The CICAD Executive Secretariat supports the Commission by strengthening the human and institutional capabilities and channeling the collective efforts of its member states to reduce the production, trafficking and use of illegal drugs. The Hemispheric Drug Strategy, approved in May 2010, expresses the firm commitment of member states to deal with the consequences of the drug trade, which pose a growing threat to health, economic development, social cohesion, and the rule of law (OAS, 2017a).

CICAD promotes regional cooperation and coordination among OAS member states through action programs, carried out by CICAD's Executive Secretariat, to: 1) Prevent and treat substance abuse; 2) Reduce the supply and availability of illicit drugs; 3) Strengthen national drug control institutions and machinery; 4) Improve money laundering control laws and practice; 5) Develop alternate sources of income for growers of coca, poppy, and marijuana; 6) Assist member governments to improve their data gathering and analysis on all aspects of the drug issue, and 7) Help member states and the hemisphere as a whole measure their progress over time in addressing the drug problem (OAS, 2017a).

Table 1. Directory of Member States and Representatives (OAS, 2012)

\begin{tabular}{lll}
\hline \multicolumn{3}{c}{ Member States of CICAD } \\
\hline 1. Antigua \& & 12. Dominica & 24. Panama \\
2. Argentina & 13. Dominican & 25. Paraguay \\
3. Bahamas & \multicolumn{1}{c}{ Republic } & 26. Peru \\
4. Barbados & 14. Ecuador & 27. Saint Kitts \& Nevis \\
5. Belize & 15. El Salvador & 28. Saint Lucia \\
6. Bolivia & 16. Grenada & 29. St Vincent \& \\
7. Brazil & 17. Guatemala & 18. Guyana \\
8. Canada & 19. Haiti & 30. Suriname \\
9. Chile & 20. Honduras & 32. Uninidad \& Tobago \\
10. Colombia & 21. Jamaica & 33. Uruguay \\
11. Costa Rica & 22. Mexico & 34. Venezuela \\
\end{tabular}


CICAD's core mission is to enhance the human and institutional capacities of its member states to reduce the production, trafficking and use of illegal drugs, and to address the health, social and criminal consequences of the drug trade. CICAD is the OAS agency that: 1) Serves as the Western Hemisphere's policy forum on all aspects of the drug problem; 2) Fosters multilateral cooperation on drug issues in the Americas; 3) Executes action programs to strengthen the capacity of CICAD member states to prevent and treat licit and illicit drug abuse; combat production of illicit drugs, and deny the traffickers their illegal profits; 4) Promotes drug-related research, information exchange, specialized training, and technical assistance; and 5) Develops and recommends minimum standards for drug-related legislation, treatment, the measurement of both drug consumption and the cost of drugs to society, and drug-control measures, among others; and 6) Carries out regular multilateral evaluations of progress by member states in all aspects of the drug problem.

CICAD is able to legitimate US influence on Latin American countries that experience the political and health problems because of drug trafficking. CICAD accomodate international cooperation involve institutional capacity building, technical and financial assistance to reach the state interest on drug control policy. The mechanism of cooperation among US and Latin America countries could be define from the CICAD framework of cooperation as followed:

1.) CICAD: Inter-American Observatory on Drugs (OID)

The Inter-American Observatory on Drugs (OAS, 2015) is CICAD's statistical, information and scientific research branch. Informed by a sound, evidence-based picture of the drug problem, both nationally and at the hemispheric level, member states can better understand all the dimensions of the drug problem, and design and implement policies and programs to address them. The Observatory helps countries to improve the collection and analysis of drug-related data: by promoting the establishment of national observatories and the use of standardized methods and data; and by providing scientific and technical training for, and the exchange of experiences among, professionals working on drug issues. See the relevant guidelines on evidence-based policies and scientific research in the Hemispheric Drug Strategy. 
OID mission is to help promote and build a drug information network for the Americas that offers objective, reliable, up-to-date and comparative information so that member states can better understand, design and implement policies and programs to confront the drug phenomenon in all its dimensions. Created in 2000, the Observatory supports hemispheric policy and cooperation by examining the crucial nexus of supply and demand within the hemisphere and vis-àvis other regions of the world. It has the potential to serve as an early warning system on the appearance of new drugs, new methods of using and manufacturing drugs, and changing trafficking patterns.

From its mission and vision, as well as the objectives set, the OID provides technical assistance to member states in order to 1) Helping countries improve the collection and analysis of drug-related data; 2) Promoting the establishment of national drug observatories and the use of standardized data systems and methodologies; and 3) Providing scientific and technical training for and the exchange of experiences among professionals working on the drug problem.

2.) CICAD: Anti-Money Laundering (AML)

CICAD's Anti-Money Laundering (OAS, 2014) Section was established in late 1999, due to CICAD's increased activities of training and assisting Member States in the control of money laundering. The section focuses its efforts on providing technical assistance and training on judicial, law enforcement and financial matters. It also acts as the technical secretariat of CICAD's Expert Group on the Control of Money Laundering.

The Expert Group is the hemispheric forum to discuss, analyze and draft policies to deal with money laundering and the financing of terrorism. Through this expert group, which was founded in 1990 under the Legal Development Unit, the Model Regulations on Money Laundering Offenses Related to Drug Trafficking and Other Criminal Offenses were drafted and approved in 1992. These regulations serve as a permanent legal reference document to provide a legal framework to Member States.

The Anti-Money Laudering Section works with international and national institutions to develop training activities and technical assistance. The main partners are the Inter-American Development Bank (IADB), the Bureau of 
International Narcotics and Law Enforcement Affairs (INL) of the U.S. Department of State, the Ministry of Interior and the Plan Nacional de Drogas of Spain, and the United Nations Office on Drugs and Crime (UNODC). Similar cooperation links were established with the governments of Canada and France for joint training efforts in the region. CICAD has trained more than 1,800 officials to date.

In 1999, the IADB-CICAD project for training employees of banking and financial supervisory institutions was initiated in eight South American countries. In 2001, another program was developed to work with judges and prosecutors in eight South American countries. In 2002, a project to create and strengthen financial intelligence units in was initiated in Argentina, Brazil, Chile, Ecuador, Peru, Uruguay, and Venezuela.

3.) CICAD: Multilateral Evaluation Mechanism (MEM)

The US leadership on drug control policy is able to analysis from the multilateral evaluation mechanism of CICAD. The objective of the MEM (OAS, 2017c) is directly to strengthen mutual confidence, dialogue and hemispheric cooperation in order to deal with the drug problem with greater efficacy. It follows the progress of individual and collective efforts of all the countries participating in the Mechanism, indicating both results achieved as well as obstacles faced by the countries. Other objectives of the MEM are identifies the strengths, weaknesses, progress, and setbacks in each member state and of the hemisphere, in order to help orientate policies and programs to confront more effectively the drug problem. It assists countries in generating internal support to fight the drug problem and stimulating change and development of the systems in drug control. It offers countries the opportunity to request technical or financial assistance and training to implement the MEM recommendations.

MEM is periodic recommendations to member states on improving their capacity to control drug trafficking and abuse and enhance multilateral cooperation. It was proposed at the Second Summit of the Americas in 1998. The Heads of State and of Government of the Americas turned the concept of multilateral evaluation into a mandate, declaring in the Plan of Action that their countries would undertake the following specific action: 


\begin{abstract}
"Continue to develop their national and multilateral efforts in order to achieve full application of the Anti-Drug Strategy in the Hemisphere, and will strengthen this alliance based on the principles of respect for the sovereignty and territorial jurisdiction of the States, reciprocity, shared responsibility and an integrated, balanced approach in conformity with their domestic laws;

With the intention of strengthening mutual confidence, dialogue and hemispheric cooperation and on the basis of the aforementioned principles, develop, within the framework of the Inter-American Drug Abuse Control Commission (CICAD-OAS), a singular and objective process of multilateral governmental evaluation in order to monitor the progress of their individual and collective efforts in the Hemisphere and of all the countries participating in the Summit, in dealing with the diverse manifestations of the problem."
\end{abstract}

Based on these mandates and in order to execute them, the twenty-third regular session of CICAD (May 1998) formed an Inter-Governmental Working Group on the Multilateral Evaluation Mechanism (IWG-MEM) headed by Canada and Chile, in order to design the mechanism to begin in 1999.

The Multilateral Evaluation Mechanism (MEM) is an instrument designed to measure the progress of actions taken by the 34 member states of the Inter-American Drug Abuse Control Commission (CICAD). This evaluation is carried out through the elaboration and publication of national and hemispheric reports on the progress in drug control. Acting on a mandate from the Second Summit of the Americas, the MEM was created in 1999 with the objective of increasing coordination, dialogue, and cooperation within the 34 member states in order to confront the drug problem more efficiently.

The evaluation reports produced during the MEM process are drafted by government experts designated by OAS member states. Each country is entitled to one main expert and alternate experts, with the specification that each country has only one voice, and experts do not participate in the evaluation of their own country. These experts compose the Governmental Expert Group (GEG), a multidisciplinary group that ensures the objectivity and the multilateral component of the MEM. The principles of the MEM process develop as followed: 1) Respect for sovereignty, territorial jurisdiction, and the domestic laws of States; 2) Reciprocity, shared responsibility and an integrated balanced approach to this issue; 3) Observance of the 
Anti-Drug Strategy in the Hemisphere and international agreements and instruments in force.

\section{The US Interest on Political Economy and National Security}

\section{a. Latin America as US Market}

US believe in market reform and American pragmatism based on democracy and trade liberalization. US government influence the Latin America countries as socialist regimes through trade liberalization. In the beginning, US perceived that his neighbour countries will change based on the advantages and interdependence of Mercosur as common market. Surprisingly, Mercosur reach the significant improvement that challenge the US trade interest to Latin American countries. The economic advancement of Mercosur triger the confidence building among Latin America countries and let them survive without US political influence.

Whereas, US national security threaten by the increasing of drug trafficking from Mexico and southern area sinnce 1980s. The OAS framework of cooperation on combating drugs trafficking developed by US as the dominant actor to legitimate the US influence in American regional forum. By strengthening the US and Latin America cooperation on drugs control the US administration is able to contribute to the economic benefits of Mercosur and achieve US policy on drug control throughout the American region.

This paper argue that US acknowledge the economic rising of Latin American countries through the creation of regional trade agreement called Mercosur. US have to strengthened the economic cooperation with Mercosur countries due to take benefits from the economic growth that means as US market in this region. By considering the economic cooperation, US can maintain its influence in the matter of democracy and market liberalization. Unfortunately, the success of Mercosur probably triger the independence of Latin America toward US power. Therefore, it needs regional issue to connect the US influence to its newly emerging power neighbourhood states as so called drugs control policy.

Mercosur is an abbreviation of the Spanish Latin, the Mercado Comun del Sur. It is known as the common market of the South. Mercosur is a regional organization in South America formed in 1991. Mercosur was born by initiatives of 
Latin American countries such as Brazil, Argentina, Uruguay, and Paraguay. The organization is concerned with promoting economic development and free trade. Mercosur developed from the desire of countries to integrate Latin American economy through America Free Trade Association (AFTA) in 1960 and through its predecessor the Latin American Integration Association in 1980. Early history of the formation of Mercosur began in 1985 in which Brazil and Argentina signed the Iguacu Declaration. The Iguacu Declaration aims to form bilateral committees to promote the economies of the two sides which subsequently develop into trade negotiations. In 1988 Brazil and Argentina signed an agreement for integration, cooperation, and development commitments that worked towards establishing the market within 10 years and inviting other countries to join. This is evident from the reduction of all tariff barriers and the harmonization of macroeconomic policies of both countries.

Mercosur was formed in 1991 marked by the signing of the Asuncion Agreement by Argentina, Brazil, Paraguay, and Uruguay as the founders and permanent members of this regional organization. Countries that are still in the process of ratification of membership are Venezuela, while the countries that are members of this association are Bolivia, Chile, Colombia, Equador, Peru. In the subsequent years precisely in 1994, the Mercosur organizational structure of The Ouro Preto Protocol was established, giving Mercosur a wider and growing international status in the Custom Union scheme.

On 1 January 1995, many attempts by Mercosur included reducing internal tariffs (tariffs imposed between members), free trade and customs zones were formally established. Despite the smooth progress, there are still obstacles to the association, including import taxes, and although members agree on import tariffs on non-members, there are still constraints in the division of tasks. In 1996 the Parliament of the Joint Commission, comprising parliaments of member states, stated that all members who participated in Mercosur had to function as democratic institutions. In 2003, Mercosur signed a free trade agreement with the Andean community, which came into force on 1 July 2004. In 2007 the new parliament of member countries was inaugurated in Montevideo. In 2012, after the controversial dismissal of Paraguay President Fernando Lugo, Brazil, Argentina and Uruguay took 
the decision to postpone Paraguay membership until 2013. Then at the same summit where actions taken by leaders of three member states actively announced Venezuela's rise for membership full, valid from 31 July 2012. Mercosur consists of two members. It is called Permanent Members and Associate Members. Permanent Members involves the founding member states of Mercosur that consist of Argentina, Brazil, Paraguay, Uruguay and Venezuela.

\begin{abstract}
"MERCOSUR members (Brazil, Argentina, Paraguay, and Uruguay founding members, and Venezuela, which completed its accession process in the middle of 2012) encompasses approximately $72 \%$ of the territory of South America (12.8 million $\mathrm{km} 2$, equivalent to three times the area of the European Union); $70 \%$ of the South American population (275 million inhabitants) and 77\% of South America's GDP in 2012 (US\$ 3.18 trillion from a total of US $\$ 4.13$ trillion, according to World Bank data). In December 2012, with the signing of the Protocol of Accession of the Plurinational State of Bolivia to MERCOSUR, the accession process as a member State has started. Chile, Peru, Colombia, and Ecuador are Associate members of MERCOSUR, in addition to Guiana and Suriname, which acquired this status in July 2013. All South American countries are linked to MERCOSUR, either as member State or Associate member."(Ministry of Foreign Affairs, n.d.)
\end{abstract}

Based on regionalism perspective, the development of Mercosur is able to attract investment and rise trade volume among its member. The leadership of Brazil and Argentina through the common market of Mercosur bring economic advantages within Latin America region. Mercosur challenges the economic power of NAFTA where the US appear as the founding father. Richard L. Harris \& Jorge (2008) notice that US acknowledge Mercosur as the US new strategy to expand its capital market in Latin America countries. By considering the economic benefits, US is able to influence the administration of Latin America countries. It is common as the theory of democratic peace where the state is welfare, the war is less exist. This phenomenon shows that regionalism perspective infuence the matter of geopolitics between western and latin america countries.

Mercosur not only focuses on the economic field by striving to eliminate trade barriers, such as high customs and income inequality but also expand the dimension of cooperation in the fields of politics, culture and even security. However, the role of Mercosur is pioneered by the initiative of two major countries, known as 'Two Giants' in South America, namely Argentina and Brazil. Mercosur as 
a form of regional cooperation in South America continues to seek economic improvement and regional integration by engaging in inter-State cooperation and building cooperation with other regional organizations. MERCOSUR's crucial role in the economy and trade in South America brings results as the world's fourth largest trading bloc after the European Union, NAFTA and ASEAN (Lorenzo and Vaillant, 2003; Azizah, 2014).

\section{b. Drugs Trafficking as the Threat of US National Security}

US government concerned on drugs control since the end of cold war. The increasing of drugs consumtion relates to the raising of crime and violence. Then, the problem of drug trafficking is not only threat for US national security but also people health. Drugs control policy is implemented as a part of US political, judicial, and economic agenda of its administration. US recognized drugs trafficking is not only the domestic issue but refers to regional chellenges. US neighbour countries at the south becomes source of worried.

The history of cocaine trafficking from South America to the United States has been well documented. The flow peaked in the 1980s. During most of this time, Colombian traffickers dominated the market, and they often preferred to use the Caribbean as a transit area. Due to vigorous law enforcement, the Colombian groups were weakened in the 1990s, and Mexican groups progressively assumed control of most of the trafficking chain. As a product of this shift, an ever-increasing share of the cocaine entering the United States did so over the southwestern land border. Initially, direct shipments to Mexico were favoured, with stopovers in Central America largely limited to refueling. After 2000, and especially after 2006, law enforcement increased the risks of shipping directly to Mexico. Consequently, Central America took on new importance as a transit and storage area, and parts of the Caribbean were reactivated (UNODC, 2012a).

In the mid-1980s, over $75 \%$ of the cocaine seized between South America and the United States was taken in the Caribbean, and very little was seized in Central America. By 2010, the opposite was true: over 80\% was seized in Central America, with less than 10\% being taken in the Caribbean. The bulk of the cocaine seized in recent years in the Caribbean has been taken by the Dominican Republic, which is also a transit country for the European market (UNODC, 2012a).

Based on the International Narcotics Control Strategy Report (INCSR) Mexico remains a major transit countries for cocaine and heroin and the place of production for heroin, marijuana, and methamphetamine sent to US market. 
The Government of Mexico reported eradicating 21,425 hectares (ha) of opium poppy in 2014, a significant increase from the 14,419 ha eradicated in 2013 . The Government of Mexico also reported eradicating 5,679 ha of cannabis in 2014, a slight increase over the 5,096 ha eradicated in 2013. The Office of the Attorney General reported Mexico seized 929.4 MT of marijuana in 2014, a decrease of 3.0 percent from 2013. Mexico seized 3.6 MT of cocaine, a 41.5 percent decrease, and 1.4 MT of opium gum in 2014, an increase of over 400 percent. U.S. law enforcement seizures of heroin along the U.S.-Mexico border have also increased significantly over the past several years. With respect to synthetic drugs, Mexican seizures of methamphetamine, which totaled 19.8 MT in 2014, increased 35.9 percent when compared to 2013. Seizures of clandestine drug labs rose slightly. The Mexican government seized 143 labs in 2014, an 11.7 percent increase compared to 2013. Mexican officials participate in regular meetings with U.S. experts to identify and target the latest trends in synthetic drug production (Bureau of Public Affairs, 2016).

Maritime and land corridors through Central America and Mexico continue to be the most significant transit routes for cocaine from South America bound for the United States. Therefor, Mexico participates with Canada and the US in the North American Maritime Security initiative, in which naval authorities meet regularly to share information, improve response to transnational crime. Mexico hosted a trilateral police chief meeting with Canada and the US in 2015 (Bureau of Public Affairs, 2016).

According to Mexico's statistics agency (INEGI) in September 2015, homicides decreased by nearly 15 percent and kidnappings decreased by 22 percent from 2013 to 2014. However, an estimated 93 percent of all crimes went either unreported or uninvestigated in 2014. Mexico has suffered a wave of drug-related violence since then-President Felipe Calderon sent the army to combat drug cartels in 2006. The 'nothern triangle' of Central America - Guatemala, Honduras, and El Salvador- has some of the highest homicide rates in the world. Colombia, despite having broken up powerful cartels and curtailed coca production, still suffers rising violence in regions where traffickers and other criminal groups remain most active, such as the Valle de Cauca. Moreover, Carribean countries also faced the problem of drug trafficking. In the Netherlands Antilles, authorities estimate that 75 percent of crime is drug-related. Some 60 percent of all the cocaine seized in the Caribbean in 2004 was seized in the Netherlands Antilles, and cocaine seizures there increased dramatically between 2001 and 2004. Confronted with large numbers of people attempting to smuggle drugs by commercial flights, authorities implemented a " $100 \%$ 
Control" policy of screening large numbers of passengers for drugs. Drugs were confiscated from the couriers, but in most cases the couriers themselves were not arrested (Bureau of Public Affairs, 2016; Speck, 2013; UNODC, 2007, 2012b).

\section{Conclusion}

Current U.S. policy toward the region is focused on four priorities: promoting economic and social opportunity; ensuring citizen security; strengthening effective democratic institutions; and securing a clean energy future. There has been substantial continuity in U.S. policy toward the region under the Obama Administration, which has pursued some of the same basic policy approaches as the Bush Administration.

Nevertheless, the Obama Administration has made several significant policy changes, including an overall emphasis on partnership and shared responsibility. This paper argue that US acknowledge the economic rising of Latin American countries through the creation of regional trade agreement called Mercosur. US have to strengthened the economic cooperation with Mercosur countries due to take benefits from the economic growth that beneficial for prospect of US market. By considering the economic cooperation, US can maintain its influence in the matter of democracy and market liberalization. Unfortunately, the success of Mercosur probably triger the independence of Latin America toward US power. Therefore, it needs regional issue - "drugs control policy" to re-connect the US influence to its emerging power neighbourhood states.

\section{References}

Arya, N. (2013). MERCOSUR Mercado Comun Del Sur: Common Market of the South A Study on the Origins, Organizational Structure, Latest Developments and the Contemporary Trade Patterns of MERCOSUR. Retrieved from http://www.icwa.in/pdfs/SHP022013.pdf

Bureau of Public Affairs. (2016). 2016 International Narcotics Control Strategy Report (INCSR): $\quad$ Mexico. $\quad$ Retrieved from https://www.state.gov/j/inl/rls/nrcrpt/2016/vol1/253288.htm

Chatterjee, R. (2016). Mercosur: A Brief History. Pulsamerica: The Impartial Latin 
American News Magazine. Retrieved from www.pulsamerica.co.uk/2015/07/mercosur-a-brief-history/

DiPasquale, D., Pitts, D. P., \& Bronk, K. (n.d.). Barack Obama 44th President of The United States. (G. Clack, Ed.). United States Department of State. Retrieved from https://photos.state.gov/libraries/jerusalem/328666/obama_pdfs/oba maen.pdf

Earl R., B. (2010). The Practice of Social Research (12th ed.). Belmont CA: Wadsworth Cengage.

Fadihatul Husna, A. (2012). Perubahan Kebijakan Luar Negeri Amerika Serikat dalam Memerangi Terorisme Internasional di Afghanistan Pada Periode Pemerintahan Barack Obama. UIN Syarif Hidayatulah Jakarta. Retrieved from http://www.repository.uinjkt.ac.id/dspace/bitstream/123456789/24093 /1/ATIK.pdf

Hanson, S. L. (2014). TRANSFORMATIONAL LEADERSHIP AND COMMUNICATION: BARACK OBAMA CASE STUDY. San Diego State University. Retrieved from https://sdsudspace.calstate.edu/bitstream/handle/10211.3/115573/Hanson_sdsu_0 220N_10194.pdf

Holsti, K. J. (1983). Politik Internasional Kerangka Untuk Analisis (terj.) (Forth). Jakarta: Erlangga.

Jackson, R., \& Sorensen, G. (1999). Introduction to International Relations. New York: Oxford University Press.

Jemadu, A. (2008). Politik Global dalam Teori \& Praktik. Yogyakarta: Graha Ilmu.

Kegley Jr., C. W., \& Wittkopf, E. R. (1999). World Politics: Trend and Transformation (Seventh). United States of America: Macmillan Press, Ltd.

King, G., Keohane, R. O., \& Verba, S. (1994). Designing Social Inquiry: Scientific Inference in Qualitative Research. New Jersey: Princeton University Press.

Ministry of Foreign Affairs. (n.d.). Mercosur. Retrieved from http://www.itamaraty.gov.br/en/politica-externa/integracaoregional/6347-mercosur-en

Nguyen, H. T. T. (2014). Theories of US Foreign Policy: An Overview. World Journal 
of Social Science, 1(1), 20-26. https://doi.org/10.5430/wjss.v1n1p20

OAS. (2012). Directory of Member States. Retrieved November 20, 2017, from http://www.cicad.oas.org/Main/Template.asp?File=/main/aboutcicad/ directory/directory_eng.asp

OAS. (2014). Anti-Money Laundering. Retrieved August 23, 2017, from http://www.cicad.oas.org/Main/Template.asp?File=/lavado_activos/de fault_eng.asp

OAS. (2015). Inter-American Observatory on Drugs (OID). Retrieved August 23, 2017 , from http://www.cicad.oas.org/Main/Template.asp?File=/oid/default_eng.a sp

OAS. (2016a). CICAD Executive Secretariat. Retrieved November 19, 2017, from http://www.cicad.oas.org/Main/Template.asp?File=/main/aboutcicad/ history/secretariat_eng.asp

OAS. (2016b). Commission Chairs. Retrieved November 20, 2017, from http://www.cicad.oas.org/Main/Template.asp?File=/main/aboutcicad/ history/presidents_eng.asp

OAS. (2017a). About CICAD. Retrieved November 19, 2017, from http://www.cicad.oas.org/Main/Template.asp?File=/Main/AboutCIC AD/about_ENG.asp

OAS. (2017b). Drugs. Retrieved November 19, 2017, from http://www.oas.org/en/topics/drugs.asp

OAS. (2017c). What is the MEM? Retrieved August 23, 2017, from http://www.cicad.oas.org/Main/Template.asp?File=/mem/about $/$ defa ult_eng.asp

OAS. (2017d). Who We Are. Retrieved February 9, 2017, from http://www.oas.org/en/about/who_we_are.asp

Obama, B. (n.d.). President Obama's speech after winning the "Nobel Peace Prize." Dr. Thorman Wirtschaftsenglisch. Retrieved from http://www.wirtschaftsenglisch.eu/fileadmin/user_upload/ObamaRede FriedensNobelPreisMitVokhilfen.pdf

Onyenachi Nze, S. (2010). BARACK OBAMA AND WORLD PEACE, $A$ 
RHETORICAL INQUIRY. Wichita State University. Retrieved from https://soar.wichita.edu/bitstream/handle/10057/3318/t10027_Nze.pd f?sequence $=3$

Peters, M. A. (2009). Renewing the American Dream: Obama's political philosophy. Policy Futures in Education, 7(1), 125-128. Retrieved from http://journals.sagepub.com/doi/pdf/10.2304/pfie.2009.7.1.125

Speck, M. (2013). The OAS Position on Drugs: A (Gradual) New Approach. Retrieved August 23, 2017, from http://blog.crisisgroup.org/latinamerica/mexico/2013/06/21/the-oas-position-on-drugs-a-gradual-newapproach/

Sullivan, M. P., Beittel, J. S., Leland, A., Meyer, P. J., Seelke, C. R., \& Taft-morales, M. (2012). Latin America and the Caribbean: U . S . Policy and Key Issues for Congress in 2012.

Thi, H., \& Nguyen, T. (2014). Theories of US Foreign Policy: An Overview. World Journal of Social Science, 1(1). https://doi.org/10.5430/wjss.v1n1p20

UNODC. (2007). Crime, Violence, and Development: Trends, Costs, and Policy Options in the Caribbean. Retrieved from https://www.unodc.org/pdf/research/Cr_and_Vio_Car_E.pdf

UNODC. (2012a). Cocaine from South America to the United States. Retrieved from https://www.unodc.org/documents/data-andanalysis/Studies/TOC_Central_America_and_the_Caribbean_english.pd $\mathrm{f}$

UNODC. (2012b). Transnational Organized Crime in Central America and the Caribbean: A Threat Assessment, (September), 80. Retrieved from http://www.unodc.org/documents/data-andanalysis/Studies/TOC_Central_America_and_the_Caribbean_english.pd $\mathrm{f}$

Wiarda, H. J., \& Kline, H. F. (2007). Latin American Politics and Development (Sixth). Colorado: Westview Press, Inc. 